\title{
RANCANG BANGUN TURBIN ANGIN POROS HORIZONTAL DOUBLE MULTIFLAT BLADE
}

\author{
Adityo Barik A, Nurul Faridah, Yuriska Nugraheni, Zuhair Naufal H, Wahyono, Ilyas Rochani \\ Program Studi Teknik Konversi Energi \\ Jurusan Teknik Mesin Politeknik Negeri Semarang. \\ Jl. Prof. H. Sudarto, SH., Tembalang, 50275, PO BOX 6199 / SMS Telp. (024) 7473417, 7499585, \\ Faks. (024) 7472396 \\ e-mail:secretariat@polines.ac.id
}

\begin{abstract}
Abstrak
Tujuan dari penelitian Turbin Angin Poros Horizontal Double Multiflat Blade adalah membandingan kinerja turbin angin poros horizonal single multiflat blade dengan turbin angin poros horizontal double multiflat blade perlakuan sisi masuk dan perlakuan sisi keluar. Pengujian turbin angin single multiflat blade dilakukan pada kecepatan angin $5 \mathrm{~m} / \mathrm{s}, 7 \mathrm{~m} / \mathrm{s}$, dan $9 \mathrm{~m} / \mathrm{s}$ dengan sudut blade $35^{\circ}, 38^{\circ}$, $40^{\circ}, 43^{\circ}$ dan $45^{\circ}$. Berdasarkan pengujian, turbin angin single multiflat blade pada kecepatan angin 9 $\mathrm{m} / \mathrm{s}$ dan sudut blade $40^{\circ}$ menghasilkan efisiensi sistem tertinggi yaitu 8,397\%. Kecepatan dan sudut tersebut digunakan untuk pengujian turbin angin double multiflat blade. Pengujian turbin angin double multiflat blade dengan perlakuan sisi keluar, efisiensi sistem tertinggi yaitu 11,74\%, sedangkan pengujian turbin angin double multiflat blade dengan perlakuan sisi masuk, efisiensi sistem tertinggi yaitu 5,16\%. Kesimpulan dari pengujian adalah efisiensi sistem tertinggi dihasilkan pada pengujian turbin angin poros horizontal double multiflat blade perlakuan pada sisi keluar dengankecepatan angin $9 \mathrm{~m} / \mathrm{s}$ dan sudut blade $40^{\circ}$ sebesar $11,74 \%$.
\end{abstract}

Kata kunci : Turbin angin poros horizontal, turbin angin multiblades, sudut blade, kecepatan angin, efisiensi sistem.

\section{Pendahuluan}

Konsumsi listrik di Indonesia setiap tahunnya terus meningkat sejalan dengan peningkatan pertumbuhan ekonomi nasional. Konsumsi listrik Indonesia yangbegitu besar akan menjadi masalah biladalam penyediaannya tidak sejalan dengan kebutuhan. Kebutuhan pasokan energy listrik yang terus-menerus dan berkualitas menjadi tuntutan yang harus dipenuhi oleh negara. Untuk mengatasi pemenuhan kebutuhan listrik tersebut, maka diperlukan sumber energi baru yang mampu memenuhi kebutuhan listrik nasional yang semakin besar.

Beberapa sumber energi alternatif dapat dimanfaatkan sebagai pembangkit listrik, seperti energi air (PLTA dan PLTMH), energi panas bumi (PLTPB), energi sinar matahari (Solar Photovoltaic / PLTS), dan energi angin (PLTB). Energi air, energi panas bumi, dan energi sinar matahari dalam pemanfaatannya membutuhkan lahan yang luas dan harga peralatannya mahal. Sedangkan energi angin tidak membutuhkan lahan yang terlalu luas serta peralatannya murah dan mudah didapatkan.

Turbin angin merupakan salah satu alat yang digunakan dalam pemanfaatan energi, khususnya pemanfaatan energi angin pada salah satu pembangkit tenaga listrik. Salah satu tipe turbin angin adalah turbin angin poros horizontal. Kelebihan dari turbin angin poros horizontal yaitu efisiensinya lebih tinggi dibanding turbin angin poros vertikal karenasudu selalu bergerak tegak lurus terhadap arah angin dan menerima daya sepanjang putaran.

Turbin angin poros horizontal double multiflat blade merupakan pengembangan dari turbin angin single multiflat blade dengan penambahan penyempitan celah keluaran (air exit split) pada sepanjang keluaran sudu turbin angin. Air exit split ini akan mengakibatkankecepatan yang keluar sudu semakin besar. Hal ini akan memberikan tambahan gaya dorong pada saat sudu turbin angin berputar, sedangkan sudu yang dibuat rangkap diharapkan dapat 
meningkatkan daya yang dihasilkan sehingga efisiensi turbin akan mengalami peningkatan. Maka dariitu, kami merancang Model Turbin Angin Poros Horizontal Double Multiflat Blade.

\section{Metode Penelitian}

Berikut ini adalah rancangan desain spesifik yang akandilaksanakan dalam penelitianini.
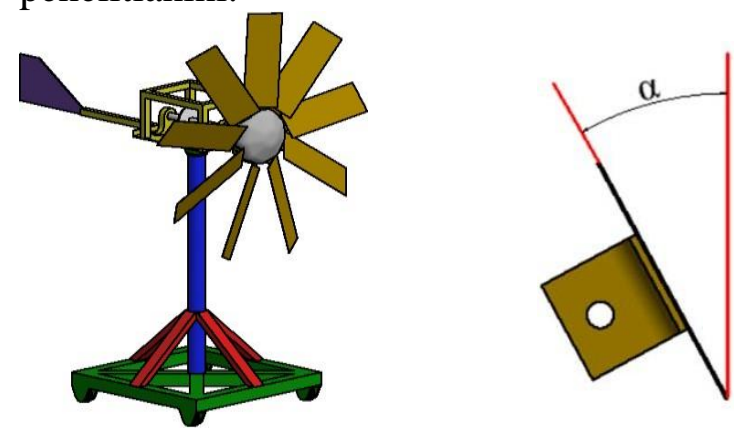

Gambar 1. Rancangan TurbinAngin Single MultiflatBlade.

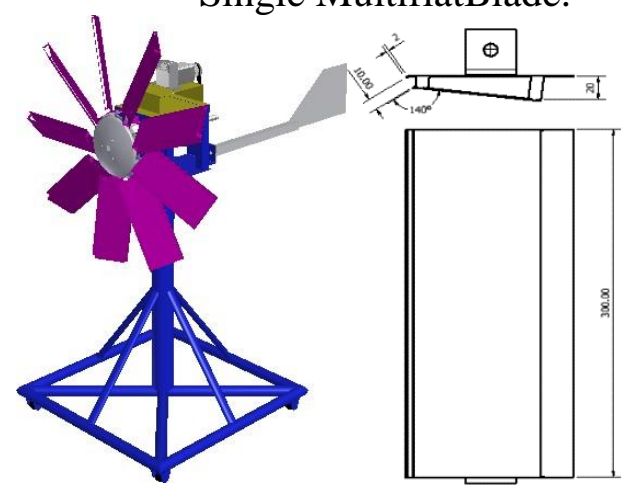

Gambar 2. Rancangan Turbin Angin Double Multiflat Blade Perlakuan SisiKeluar.

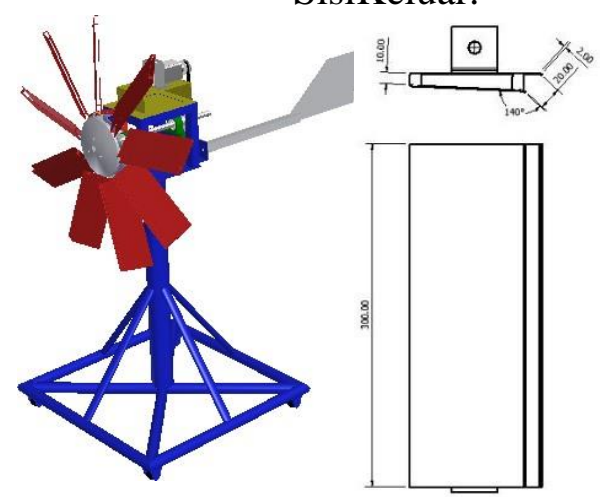

Gambar 3. Rancangan Turbin Angin Double Multiflat Blade Perlakuan Sisi Masuk.

Rancangan turbin angin ini terdiri atas sudu, hub, kerangka turbin, dan generator.Uji karakteristik efisiensiturbin dilakukan dari turbin angin single multiflat blade yang diuji pada beberapa sudut blade untuk kecepatan $5 \mathrm{~m} / \mathrm{s}, 7 \mathrm{~m} / \mathrm{s}$, dan $9 \mathrm{~m} / \mathrm{s}$ yangkemudian ditentukan sudut blade dan kecepatan angin yang menghasilkan efisiensi terbaik.

Hasil dari pengujian turbin angin single multiflat blade tersebut digunakan sebagai landasan pengujian turbin angin double multflatblade perlakuan sisi keluar dan sisi masuk. Hasil dari pengujian ketiga jenis turbin ditampilkan dalam bentuk tabel dan dilakukan perhitungan dengan persamaan-persamaan yang telah ditentukan untuk kemudian ditampilakn dalam bentuk grafik perbandingan. Perbandingan tersebut dibandingkan dengan cara deskriptif terhadap puncakpuncak nilai pada grafik karakteristik hubungan antara putaran turbin dengan efisiensi system

\section{Analisa Hasil Perhitungan Data dan Pembahasan}

Hasil perhitungan data pengujian turbin angin single multiflat blade pada kecepatan $5 \mathrm{~m} / \mathrm{s}$ dengan sudut yang lain serta data hasil perhitungan pada kecepatan $7 \mathrm{~m} / \mathrm{s}$ dan $9 \mathrm{~m} / \mathrm{s}$ dapat dilihat pada lampiran 2. Hasil pengujian turbin angin single multiflat bladepada berbagai kecepatan angin $(5 \mathrm{~m} / \mathrm{s}, 7 \mathrm{~m} / \mathrm{s}$, dan $9 \mathrm{~m} / \mathrm{s})$ diperoleh nilai efisiensi sistem tertinggi pada kecepatan $9 \mathrm{~m} / \mathrm{s}$ dan sudut blade $40^{\circ}$ dengan efisiensi sistem sebesar 8,397\%, sehingga kecepatan $9 \mathrm{~m} / \mathrm{s}$ dan sudut blade $40^{\circ}$ digunakan sebagai acuan untuk pengujian turbin angin double multiflat blade.

Data pengujian turbin angin poros horizontal double multiflat blade pada kecepatan $9 \mathrm{~m} / \mathrm{s}$ dan sudut blade $40^{\circ}$ dihitung dengan cara yang sama seperti perhitungan data pengujian single multiflat blade pada kecepatan $5 \mathrm{~m} / \mathrm{s}$ dan sudut blade $30^{\circ}$. Hasil perhitungan data tersebut ditampilkan pada Tabel 4.10 dan Tabel 4.11. digambarkan dengan analisa dangrafik berikut: 


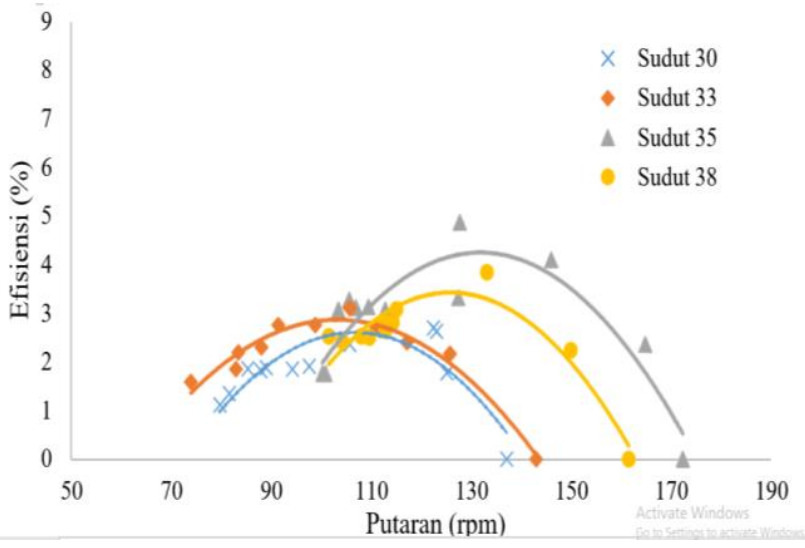

Gambar 4. Grafik Karakteristik Hubungan antara Putaran Turbin dan Efisiensi Sistem pada Kecepatan Angin Bebas $5 \mathrm{~m} / \mathrm{s}$ pada

Single Multiflat Blade

Pengujian kinerja turbin angin single multiflat blade yang pertama adalah pada kecepatan $5 \mathrm{~m} / \mathrm{s}$ dengan sudut blade $30^{\circ}$. Pengujian turbin diawali dengan beban nol (tanpa beban). Putaran yang dihasilkan pada beban ini adalah putaran maksimum yaitu sebesar 137,1 rpm, dengan tegangan sebesar 7,4 Volt, dan arus sebesar 0 Ampere. Berdasarkan hasil perhitungan dapat diperoleh dayainput sebesar 41,5894 Watt, daya output sebesar 0 Watt dan efisiensi sistem sebesar0\%.

Selanjutnya beban dinaikkan menjadi 5 Watt. Putaran yang dihasilkan menurun menjadi 125,1 rpm, dengan tegangan sebesar 4,6Volt, dan arus sebesar 0,16 Ampere. Daya input yang dihasilkan sebesar 41,4984 Watt, daya output sebesar 0,736 Watt dan efisiensi sistem sebesar $1,77 \%$.

Kenaikan beban selanjutnya yaitu beban 10 Watt, mengakibatkan putaran turun menjadi 123,1 rpm, dengan tegangan sebesar 4,2 Volt, dan arus sebesar 0,26 Ampere. Dayainput yang dihasilkan sebesar 41,4984 Watt, daya output sebesar 1,092 Watt dan efisiensi sistem sebesar $2,626 \%$.

Beban dinaikkan lagi menjadi 15 Watt. Putaran turbin turun menjadi 122,4 rpm, dengan tegangan sebesar 4 Volt, dan arus sebesar 0,28 Ampere. Daya input yang dihasilkan sebesar 41,4984Watt,dayaoutputsebesar1,12 Watt dan efisiensi sistem sebesar 2,693\%.
Efisiensi 2,693\% merupakan efisiensi tertinggi pada pengujian turbin angin single multiflat bladepada kecepatan angin $5 \mathrm{~m} / \mathrm{s}$ dengan sudut blade $30^{\circ}$. Penambahan beban dilakukan hingga beban maksimum yaitu beban 80 Watt dengan efisiensi sistem sebesar $1,116 \%$. Karakteristik hubungan antara putaran turbin dan efisiensi sistem pada kecepatan angin $5 \mathrm{~m} / \mathrm{s}$ dapat dilihat pada Gambar 4. Beban ini adalah putaran maksimum yaitu sebesar 137,1 rpm, dengan tegangan sebesar 7,4 Volt, dan arus sebesar 0 Ampere. Berdasarkan hasil perhitungan dapat diperoleh dayainput sebesar 41,5894 Watt, daya output sebesar 0 Watt dan efisiensi sistem sebesar0\%.

Selanjutnya beban dinaikkan menjadi 5 Watt. Putaran yang dihasilkan menurun menjadi 125,1 rpm, dengan tegangan sebesar 4,6Volt, dan arus sebesar 0,16 Ampere. Daya input yang dihasilkan sebesar 41,4984 Watt, daya output sebesar 0,736 Watt dan efisiensi sistem sebesar $1,77 \%$.

Kenaikan beban selanjutnya yaitu beban 10 Watt, mengakibatkan putaran turun menjadi 123,1 rpm, dengan tegangan sebesar 4,2 Volt, dan arus sebesar 0,26 Ampere. Dayainput

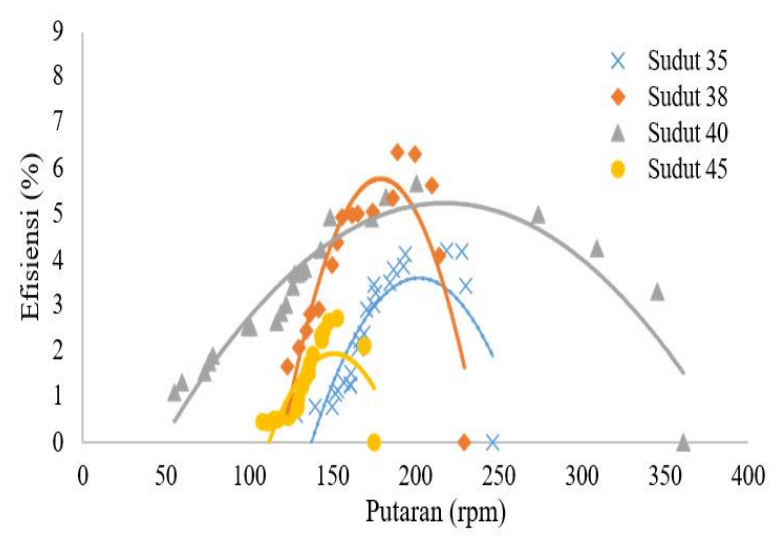

Gambar 5. Grafik Karakteristik Hubungan antara Putaran Turbin dan Efisiensi Sistem pada Kecepatan Angin Bebas 7 m/s padaSingle Multiflat Blade

Pengujian pada kecepatanangin 7 $\mathrm{m} / \mathrm{s}$ dengan sudut blade $35^{\circ}$ dilakukan sama seperti pengujian pada kecepatan $5 \mathrm{~m} / \mathrm{s}$. Dimana semakin besar beban yang ditingkatkan maka putaran akan semakin turun. Pengujian turbin pada beban nol 
menghasilkan putaran maksimum sebesar 246,5 rpm, dengan tegangan sebesar 14 Volt, dan arus sebesar 0 Ampere. Berdasarkan hasil perhitungan dapat diperoleh daya input sebesar 61,616 Watt, daya output sebesar 0 Watt dan efisiensi sistem sebesar 0\%. Kenaikan beban (5 Watt) mengakibatkan putaran turunmenjadi230,3 rpm, dengan tegangan sebesar 9,2 Volt, dan arus sebesar 0,23 Ampere. Daya input yang dihasilkan sebesar 61,616 Watt, daya output sebesar 2,116 Watt dan efisiensisistem sebesar3,434\%.

Efisiensi sistem mengalami peningkatan hingga diuji pada beban 15 Watt dengan putaran turbin $218,9 \mathrm{rpm}$ dan efisiensi sistem sebesar 4,207\%. Penambahan beban dilakukan hingga beban maksimum yaitu beban 180 Watt dengan efisiensi sistem sebesar 0,609\%.

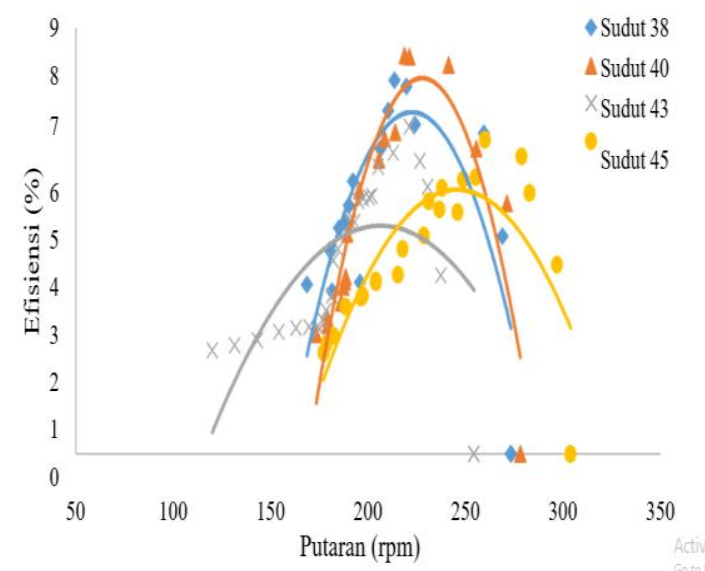

Gambar 6. Grafik Karakteristik Hubungan antara Putaran Turbin dan Efisiensi Sistem pada Kecepatan Angin Bebas $9 \mathrm{~m} / \mathrm{s}$ pada Single Multiflat Blade

Pengujian turbin angin single multiflat blade yang terakhir adalah pengujian pada kecepatan angin $9 \mathrm{~m} / \mathrm{s}$ dengan sudut blade $38^{\circ}$. Pengujian ini dilakukan sama seperti pengujian padakecepatan $5 \mathrm{~m} / \mathrm{s}$. Dimana semakin besar beban yang ditingkatkan maka putaran akan semakin turun. Pengujian turbin pada diawali dengan beban nol menghasilkan putaran maksimumsebesar 273,2 rpm, dengan tegangan sebesar 15,5
Volt, dan arus sebesar 0 Ampere. Berdasarkan hasil perhitungan dapat diperoleh dayainput sebesar 74,595 Watt, daya output sebesar 0 Watt dan efisiensi sistem sebesar0\%.

Penambahan beban menjadi 5 Watt mengakibatkan putaran turun menjadi 268,9 rpm, dengan tegangan12 Volt, dan arus sebesar 0,285 Ampere. Daya input yang dihasilkan sebesar 74,595 Watt, daya output sebesar 4,585 Watt dan efisiensisistem sebesar4,585\%.

Efisiensi sistem terus mengalami peningkatan saat beban ditambahkan hingga pengujian pada beban 25 Watt dengan putaran turbin 213,5 rpm, menghasilkan efisiensi sistem tertinggi 4,207\%. Penambahan beban dilakukan hingga beban maksimum yaitu beban 120 Watt dengan efisiensi sistem sebesar $3,42 \%$.

Berdasarkan grafik-grafik dan Tabel 4.12 di atas, untuk pengujian turbin dengan kecepatan angin $5 \mathrm{~m} / \mathrm{s}$ (kecepatan angin rendah) diperoleh nilai efisiensi tertinggi pada saat pengujian turbin dengan sudut blade $35^{\circ}$ yaitu sebesar $4,87 \%$. Sedangkan pada pengujian turbin dengan kecepatan angin $7 \mathrm{~m} / \mathrm{s}$ (kecepatan angin menengah) diperoleh nilai efisiensi tertinggi pada saat pengujian turbin dengan sudut blade $38^{\circ}$ yaitu sebesar 6,36\%. Pengujian turbin dengan kecepatan angin $9 \mathrm{~m} / \mathrm{s}$ (kecepatan angin tinggi) diperolehnilai efisiensi tertinggi pada saat pengujian turbin dengan sudut blade $40^{\circ}$ yaitu sebesar $8,397 \%$. Berdasarkan uraian tersebut, turbin angin poros horizontal single multiflat blade mempunyai efisiensi tertinggi sebesar $8,397 \%$ saat dilakukan pengujian pada kecepatan $9 \mathrm{~m} / \mathrm{s}$ dengan sudut blade $40^{\circ}$.

Hasil uji turbin angin poros horizontal single multiflat blade diperoleh efisiensi tertinggi pada kecepatan $9 \mathrm{~m} / \mathrm{s}$ dengan sudut blade $40^{\circ}$. Hasil uji tersebut digunakan sebagai landasan pengujian turbin angin poros horizontal double multiflat blade dengan perlakuan bagian sisi masuk sudu dan sisi keluar sudu. Seperti yang telah diterangkan pada sub bab $4.1 \mathrm{~b}$. 


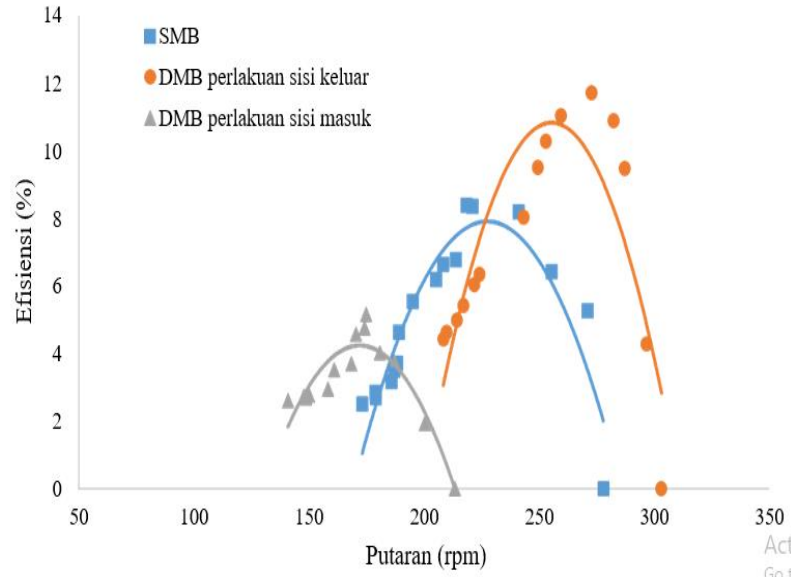

Gambar 7. Grafik Karakteristik Hubungan antara Putaran Turbin dan Efisiensi Sistem pada Kecepatan Angin Bebas 9 m/s Double Multiflat Blade

Gambar 7 menggambarkan grafik karakteristik hubungan antara putaran turbin dan efisiensi system pada pengujian turbin angin poros horizontal single multiflat blade dan turbin angin poros horizontal double multiflat blade perlakuan sisi keluar dan sisimasuk yang diuji pada kecepatan $9 \mathrm{~m} / \mathrm{s}$ dengan sudut blade $40^{\circ}$.

Berdasarkan grafik tersebut, dapat diketahui bahwa pada turbin angin poros horizontal double multiflat blade dengan perlakuan sisi keluar mempunyai efisiensi sistem tertinggi yaitu sebesar $11,74 \%$. Sedangkan pada pengujian turbin angin poros horizontal single multiflat blade dan turbin angin poros horizontal double multiflat blade pada perlakuan sisi masuk, nilai efisiensi sistem yang dihasilkan masing-masing sebesar sebesar 8,397\% dan $5,16 \%$.Pada sudut blade yang sama $\left(40^{\circ}\right)$, dengan kecepatan angin yang lebih rendah yaitu $5 \mathrm{~m} / \mathrm{s}$ dan $7 \mathrm{~m} / \mathrm{s}$ dilakukan pengujian ketiga model turbin dan hasilnya dapat dilihat pada lampiran 2 dan untuk lebih jelasnya dapat dilihat pada Gambar 8 dan Gambar 9.

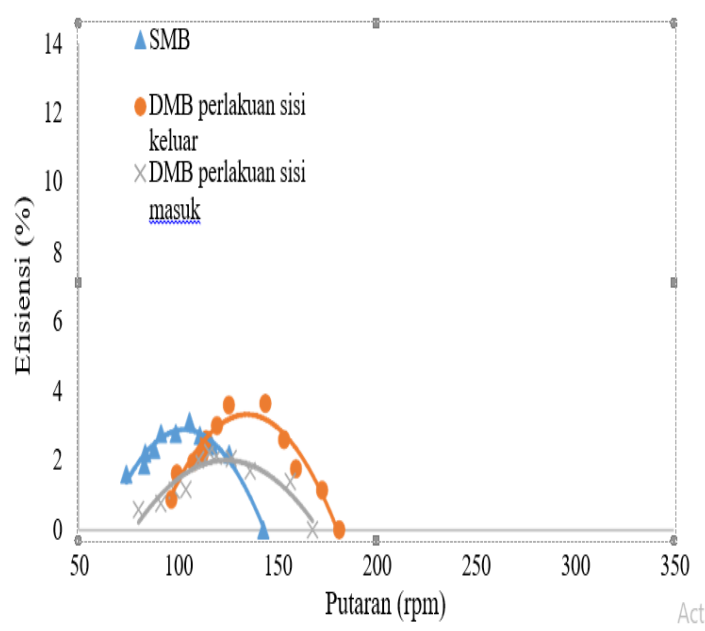

Gambar 8. Grafik Karakteristik Hubungan antara Putaran Turbin dan Efisiensi Sistem pada Kecepatan Angin Bebas 5 m/s Double MultiflatBlade

Gambar 8. Menggambarkan karakteristik hubungan antara putaran turbin dan efisiensi sistem pada kecepatan 5 $\mathrm{m} / \mathrm{s}$ dengan sudut blade $40^{\circ}$. Berdasarkan grafik tersebut, turbin angin poros horizontal double multiflat blade pada perlakuan sisi keluar mempunyai efisiensi system tertinggi yaitu sebesar 3,62\%. Sedangkan pada pengujian turbin angin poros horizontal single multiflat blade dan turbin angin poros horizontal double multiflat blade pada perlakuan sisi masuk, nilai efisiensi sistem yang dihasilkan masing-masing sebesar sebesar $3,1 \%$ dan $2,11 \%$.

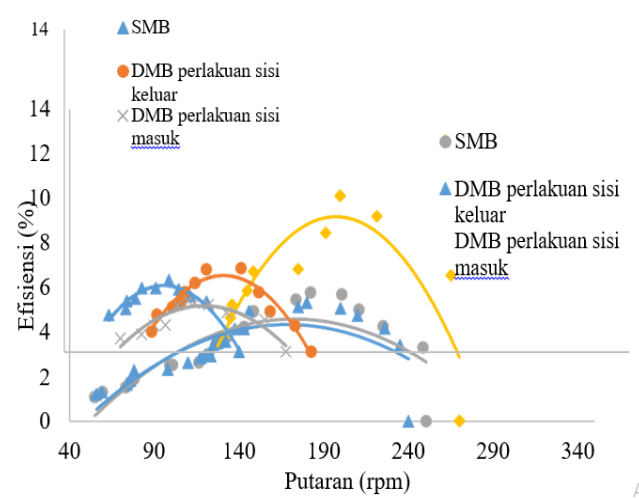

Gambar 9. Grafik Karakteristik Hubungan antara Putaran Turbin dan Efisiensi Sistem pada Kecepatan Angin Bebas 7 m/s Double Multiflat Blade 
Pengujian turbin angin poros horizontal double multiflat blade perlakuan sisi keluar pada kecepatan $7 \mathrm{~m} / \mathrm{s}$ dengan sudut blade $40^{\circ}$ mempunyai efisiensi sistem tertinggi yaitu sebesar $10,11 \%$. Sedangkan pada pengujian turbin angin poros horizontal single multiflat blade dan turbin angin poros horizontal double multiflat blade pada perlakuan sisi masuk, nilai efisiensi sistem yang dihasilkan masingmasing sebesar sebesar 5,68\% dan 5,304\%.

Dari uraian di atas, dapat diperoleh kesimpulan bahwa turbin angin poros horizontal double multiflat blade dengan perlakuan sisi keluar mempunyai efisiensi sistem tertinggi yaitu $3,62 \%$ pada kecepatan angin $5 \mathrm{~m} / \mathrm{s}, 10,11 \%$ pada kecepatan angin $7 \mathrm{~m} / \mathrm{s}$, dan $11,74 \%$ pada kecepatan angin 9 $\mathrm{m} / \mathrm{s}$ dengan sudut blade $40^{\circ}$.

\section{KESIMPULAN}

Berdasarkan analisa data dan pembahasan di atas, maka dapat disimpulkan bahwa Turbin angin poros horizontal double multiflat blade dibuat dengan sudu flat yang terbuat dari besi plat dengan ketebalan 0,9 $\mathrm{mm}$, panjang sudu sebesar $300 \mathrm{~mm}$, dan lebar sudu sebesar $100 \mathrm{~mm}$. Bagian sisi masuk sudu dibuat dengan lebar $20 \mathrm{~mm}$, sedangkan sisi keluar sudu dibuat dengan lebar $10 \mathrm{~mm}$. Turbin ini mempunyai tinggi sebesar 1,205 $\mathrm{m}$ dengan diameter sapuan sudu sebesar $83 \mathrm{~cm}$.

Efisiensi sistem tertinggi pada pengujian turbin angin single multiflat blade untuk masing-masing kecepatan adalah $4,87 \%$ (kecepatan $5 \mathrm{~m} / \mathrm{s}$, sudut blade $35^{\circ}$ ), 6,36\% (kecepatan $7 \mathrm{~m} / \mathrm{s}$, sudut blade $38^{\circ}$ ), dan 8,397\% (kecepatan $9 \mathrm{~m} / \mathrm{s}$, sudut blade $40^{\circ}$ ). Efisiensi sistem tertinggi pada pengujian turbin angin double multiflat blade perlakuan sisi keluar dengan sudut blade $40^{\circ}$ untuk kecepatan $5 \mathrm{~m} / \mathrm{s}, 7 \mathrm{~m} / \mathrm{s}$, dan $9 \mathrm{~m} / \mathrm{s}$ masing-masing sebesar 3,62\%, $10,11 \%$, dan $11,74 \%$. Sedangkan Efisiensi sistem pada pengujian turbin angin double multiflat blade perlakuan sisi masuk dengan sudut blade $40^{\circ}$ untuk untuk kecepatan 5 $\mathrm{m} / \mathrm{s}, 7 \mathrm{~m} / \mathrm{s}$, dan $9 \mathrm{~m} / \mathrm{s}$ masing-masing sebesar $2,11 \%, 5,304 \%$ dan $5,16 \%$.
Kondisi terbaik dihasilkan oleh turbin angin poros horizontal double multiflat blade perlakuan sisi keluar dengan efisiensi sistem mencapai $11,74 \%$ pada kecepatan 9 $\mathrm{m} / \mathrm{s}$ dengan sudut blade $40^{\circ}$, dan jika dibandingkan dengan kondisi terbaik turbin angin poros horizontal single multiflat blade terdapat persentase kenaikan efisiensi sistem sebesar $39,8 \%$.

\section{Daftar Pustaka}

[1] Adlie, Taufan Arif, Fazri, \& Zulfan Efendi. (2015). Analisa Biaya Pembuatan Turbin Angin Sumbu Horizontal di Wilayah Pesisir Kota Langsa. Jurutera, 7,3.

[2] Afiffudin, dkk. 2017. RancangBangun Turbin Angin Poros Horizontal Sudu Flat Tiga Lapis Menggunakan Variasi Sudut Blade dan Jarak antar Lapis Sudu. Tugas Akhir. Semarang; Jurusan Teknik MesinPolines.

[3] Anwar, Moh. Saiful. 2008. Rancang Bangun Pembangkit Listrik Tenaga Angin pada Stasiun Pengisian Accu Mobil Listrik [proyek akhir]. Surabaya:Institut Teknologi SepuluhNovember.

[4] Aryanto, Firman dkk. 2013."Pengaruh Kecepatan Angin dan Variasi Jumlah Sudu Terhadap Unjuk Kerja Turbin Angin Poros Horizontal". Jurnal Teknik Mesin. Volume 3, Nomer 1 Mataram.

[5] Bono dkk. 2017. "Karakteristik Turbin Angin Poros Horizontal dengan

[6] Variasi Bingkai Sudu Flat Untuk Pembangkit Listrik Tenaga

Angin". http://journal.sttnas.ac.id/index.php/Re TII/article/viewFile/337/277. Mei2018)

[7] Borgnakke Clause, Sonntag Richard E. Tanpa Tahun. Thermodynamic and Transport Properties. New York : John Wiley \& Sons, Inc.

[8] Dwi, dkk. 2015. Rancang Bangun Turbin Angin Multiblade dengan Generator menggunakan Motor Sepeda Listrik sebagai Pembangkit Listrik 
TenagaBayu. Tugas Akhir. Semarang: Jurusan Teknik MesinPolines.

[9] Hau, Erich. 2006. Wind Turbines. "Fundamental, Technologies, Application, Economics 2nd edition. Springer.

[10]Herlambang, Yusuf Dewantoro. 2013. "Kajian Eksperimental Turbin Angin Multiblade Tipe Sudu Flate Plate Sebagai Penggerak Mula Pompa Air". http://download.portalgaruda.org/articl e.php?article $=134068 \&$ val Daftar Pustaka

[11] Ahlund, Karin. 2004. Investigation of the NREL NASAlAmes Wind Turbine Aerodynamics Database, Aeronautics FFASE-17290, Stockholm.

[12] Andi, 2012. Turbin Angin Ripe Propeler.http://mit.ilearning.me/kincirangin-pembangkit-listrik.

[13]Himran, Syukri. 2005. Energi Angin. CVBintang. Makassar. 